\title{
EFFECT OF PINCHING AND PACLOBUTRAZOL ON HIBISCUS ROSA-SINENSIS, L. cv. "Yellow" PLANT
}

\author{
Zeinab H. El-Sadek
}

Ornamental Plants and Landscape Gardening Res. Dept., Hort. Res. Inst., ARC, Giza, Egypt.

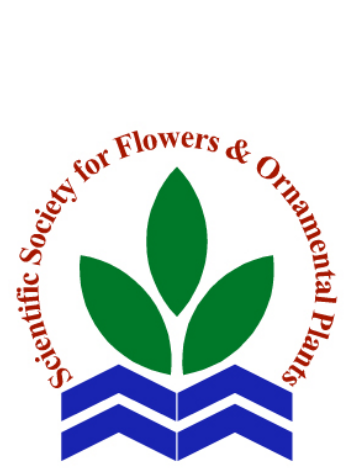

Scientific J. Flowers \& Ornamental Plants,

3(4):233-244 (2016).

Received:

8/9/2016

Revised by:

Prof. Dr. E.S. Nofal, Kafr El-Sheikh Univ.

Prof. Dr. F.M. Saadawy, Hort. Res. Inst., ARC.

ABSTRACT: A pot experiment was carried out during two successive seasons 2014/2015 and 2015/2016 at the experimental nursery of Ornamental Plants and Landscape Gardening Department, Hort. Res. Inst. to study the effect of pinching and paclobutrazol $\left(\mathrm{PP}_{333}\right)$ on growth, flowering and chemical composition of Hibiscus rosa-sinensis, L. cv. "Yellow" to produce dwarfed plants. Plants were pinched before treating with paclobutrazol $(0.0,3$ and $4 \mathrm{ppm}$ as a drench at 250 $\mathrm{cm}^{3} /$ pot, or $0.0,30$ and $40 \mathrm{ppm}$ as a foliar spray). The plants received 6 doses at one month interval during the growing season. Data revealed that pinching decreased fresh and dry weight of flowers. It also increased the content of total carbohydrates, indoles and phenols in the leaves. Pinching and spraying the plants with $\mathrm{PP}_{333}$ at $40 \mathrm{ppm}$ decreased the height of plant, while spraying $\mathrm{PP}_{333}$ at $40 \mathrm{ppm}$ without pinching increased number of leaves, length of roots and fresh and dry weight of roots. Plants sprayed with $\mathrm{PP}_{333}$ at $40 \mathrm{ppm}$ with or without pinching had higher contents of total carbohydrate, indoles and phenols. Treating plants with paclobutrazol as a drench at $4 \mathrm{ppm}$ increased chlorophyll a and b contents. It was recommended spraying pinched plants with $\mathrm{PP}_{333}$ at 40 ppm to produce dwarfed plants.

Key words: Hibiscus, pinching, paclobutrazol, growth, flowering, chemical composition.

\section{INTRODUCTION}

Hibiscus rosa-sinensis, L. cv. "Yellow" is a shrub widely distributed in temperate and tropical countries. It belongs to the family Malvaceae. Flowers are yellow. It is a showy-flowered garden shrub. It is planted alone, in groups or as a hedge. It is propagated by woody cutting in February, in loamy soil. The height of plant is about 8 meters.

Pinching is used to shape branches and change the direction of the branch. When pinching of the branch is complete, it only needs detail work or ramification. This is done by removing the tip of the growing branch, usually removing two nodes of a three node shoot. This leads to two things: 1 ) It shortens the branch. 2) It releases the buds behind it by interrupting apical dominance.
The buds are held from opening by release of a hormone (auxin) manufactured by the last bud (Walston, 2001). Songul and Ece (2015) studied the effect of pinching and paclobutrazol on ornamental pepper. They found that pinching and $\mathrm{PP}_{333}$ reduced plant height between 25 and 50\% and the canopy diameter between $8 \%$ and $17 \%$. Rezazadeh et al. (2015) on Red firespike (Odontonema strictum, Acanthaceae) reported that pinching didn't affect the number of branches. Pinching back plants can produce more flowers and leaves on a plant and helps the plant to put out energy on new growth (Rhonda, 2015)

Paclobutrazol is a plant growth regulator that slow the vegetative growth by inhibiting gibberellin biosynthesis creating more compact plants, prevent or hinder cell division in the meristem of apical and block 


\section{Zeinab H. El-Sadek}

cell elongation, and improving potted flowering shrub production. Songul and Ece (2015) studied the effect of $\mathrm{PP}_{333}$ on ornamental pepper, as they found that paclobutrazol increased total chlorophylls. Carver et al. (2014) found that the drenchapplied paclobutrazol at $40 \mathrm{mg} / \mathrm{l}$ on Borrichia frutescens (Asteraceae) reduced shoot and root masses, and reduced number of leaves and internode extension. Youssef (2013) reported that using pacloputrazol with Tabernaemontana coronaria (Apocynaceae) decreased plant height and leaf area, whereas, it significantly increased number of branches and leaves/plant. Plants sprayed with $\mathrm{PP}_{333}$ at $100 \mathrm{ppm}$ gave the heaviest fresh and dry weight of leaves/plant, and significantly increased fresh and dry weight of flower. $\mathrm{PP}_{333}$ treatments increased total carbohydrates and total chlorophylls content of leaves compared with untreated plants. YanHua et al. (2011) studied the effect of $\mathrm{PP}_{333}$ on Hibiscus rosa-sinensis and Carmona microphylla, Boraginaceae plants, they reported that it significantly inhibited growth without affecting plant's general development and ornamental quality. ElBably and Zaky (2009) using paclobutrazol with Jacobinia carnea, found that spraying paclobutrazol at $20 \mathrm{ppm}$ or as soil drench at $2 \mathrm{mg} /$ pot, twice at fortnightly intervals, was optimum for growth and flowering of $J$. carnea. El-Bably (2008) sprayed paclobutrazol on Anisacanthus wrightii, she found that most of the studied characteristics were significantly decreased due to application. The aim of the experiment, it produces dwarfed plants.

\section{MATERIALS AND METHODS}

A pot experiment was carried out during two successive seasons of 2014/2015 and $2015 / 2016$ at the experimental nursery of Ornamental Plants and Landescape Gardening Department, Horti. Res. Insti. to study the effect of pinching only or pinching with paclobutrazol $\left(\mathrm{PP}_{333}\right)$ at $0.0,3$ and 4 ppm (drench) or 30 and 40 ppm (spray) on growth, flowering and chemical composition of Hibiscus rosa-sinensis L. cv. "Yellow" plants, to produce dwarfed plant. Plants were about $30 \mathrm{~cm}$ highest, having number of leaves of about 33 and about 4 branches. The plants were individually potted (on $15^{\text {th }}$ August 2014 and 2015) in $25 \mathrm{~cm}$ plastic pots filled with a mixture of sand: peatmoss (1:1 v/v) [Table a], Plants were pinched at $22 \mathrm{~cm}$ height, with about 14 leaves and 4 branches in $19^{\text {th }}$ August. The plants received 6 doses at monthly interval during the growing season. The plants were pinched one week before being treated with $\mathrm{PP}_{333}$. After 15 days, plants were fertilized every 2 weeks with kristalon (19:19:19) at $1 \mathrm{~g} / \mathrm{l}$ (each pot was added $250 \mathrm{~cm}^{3}$ ).

Table a. Some physical properties of the growing media.

\begin{tabular}{lcccc}
\hline Season & B.D. & W.H.C \% & pH & E.C. \\
Season 1 & 1.0204 & 45.08 & 7.05 & 3.88 \\
Season 2 & 1.0998 & 49.10 & 7.17 & 2.31 \\
\hline
\end{tabular}

B.D.: Bulk density $\mathbf{g} / \mathrm{m}^{3}$

W.H.C.: Water holding capacity $\mathrm{m}^{3} / 100 \mathrm{~g}$ soil

E.C.: Electrical conductivity $\mathbf{m m o h s} / \mathbf{m}^{3}$

\section{Data recorded:}

Data were recorded on vegetative growth, flowering and chemical composition.

\section{Vegetative growth:}

- Height of plant (cm).

- Leaf area $\left(\mathrm{cm}^{2}\right)$.

- Diameter of stem (mm).

- Number of branches /plant.

- Fresh and dry weight of branches (g).

- Number of leaves /plant.

- Fresh and dry weight of leaves (g).

\section{Root characters:}

- Fresh and dry weight of roots (g).

- Length of root (cm).

\section{Flower characters:}

- Fresh and dry weight of flower (g).

- Length of flower stalk (cm). 


\section{Chemical composition:}

- Chlorophyll a, b and carotenoid (mg/100 g F.W.) was determined as described by Fahmy (1970).

- Indoles and phenols (\%) was determined as according to Larsen et al. (2006) and A.O.A.C. (2000), respectively.

- Total carbohydrates (\%) was determined as according to Herbert et al. (2005).

The experiment was laid as completely randomized in a factorial design, with 10 treatments, each treatment contained 3 replicates, and each replicate contained 3 plants. The obtained data were statistically analyzed using LSD test at 5\% (Mead et al., 1993).

\section{RESULTS AND DISCUSSION}

\section{Effect of pinching and paclobutrazol on} vegetative growth:

Data presented in Tables (1, 2 and 3) show the effect of pinching and pacloputrazol on vegetative growth of hibiscus plants.

Pinching the plants decreased height of plant and number of leaves, while it was not significantly to most the characteristics of vegetative growth. These results are agreement with those obtained of Rezazadeh et al. (2015) on Odontonema strictum.

Using paclobutrazol decreased most traits of vegetative growth compared with untreated plants. Drenching $\mathrm{PP}_{333}$ at $4 \mathrm{ppm}$ decreased fresh and dry weight of branches. These results are in agreement with those by Carver et al. (2014) on Borrichia frutescens. They found that paclobutrazol decreased shoot mass. On the other hand, spraying $\mathrm{PP}_{333}$ at $40 \mathrm{ppm}$ increased the number of leaves, while drenching $\mathrm{PP}_{333}$ at $3 \mathrm{ppm}$ gave the highest number of branches. A similar trend was obtained on Tabernaemontana coronaria by Youssef (2013) and YanHua et al. (2011) on Hibiscus rosa-sinensis and Carmona microphylla. They reported that paclobutrazol decreased plant height and leaf area. On the other hand, it increased number of branches and leaves/plant.

The interaction between pinching and paclobutrazol showed that pinching $+\mathrm{PP}_{333}$ at $40 \mathrm{ppm}$ decreased the height of plant. These results are in agreement with those by Songul and Ece (2015) on ornamental pepper. They reported that pinching and paclobutrazol decreased height of plant. Drenching $\mathrm{PP}_{333}$ at $3 \mathrm{ppm}$ without pinching recorded the highest number of branches. On the other hand, untreated plant without $\mathrm{PP}_{333}$ and pinching had more fresh and dry weight of leaves and branches, whereas spraying plants with $\mathrm{PP}_{333}$ at $40 \mathrm{ppm}$ without pinching gave the highest number of leaves.

\section{Effect of pinching and paclobutrazol on root characters:}

Data presented in Table (4) display the effect of pinching and paclobutrazol on rooting of hibiscus plant.

Pinching plants decreased fresh and dry weight and length of roots.

Spraying the plants with paclobutrazol at $40 \mathrm{ppm}$ increased fresh and dry weight of roots and length of root.

The interaction between pinching and paclobutrazol showed that spraying plants with paclobutrazol at $40 \mathrm{ppm}$ without pinching increased the most of characteristics of roots.

\section{Effect of pinching and paclobutrazol on flower characters:}

Data presented in Table (5) display the effect of pinching and paclobutrazol on flowering of hibiscus plant

Pinching plants decreased fresh and dry weight of flowers, and increased the length of the flower stalk.

Using paclobutrazol increased the fresh and dry weight of flowers, whereas it decreased the length of flower stalk compared with untreated plants. This trend was also observed by Youssef (2013) on Tabernaemontana coronaria. He stated that 


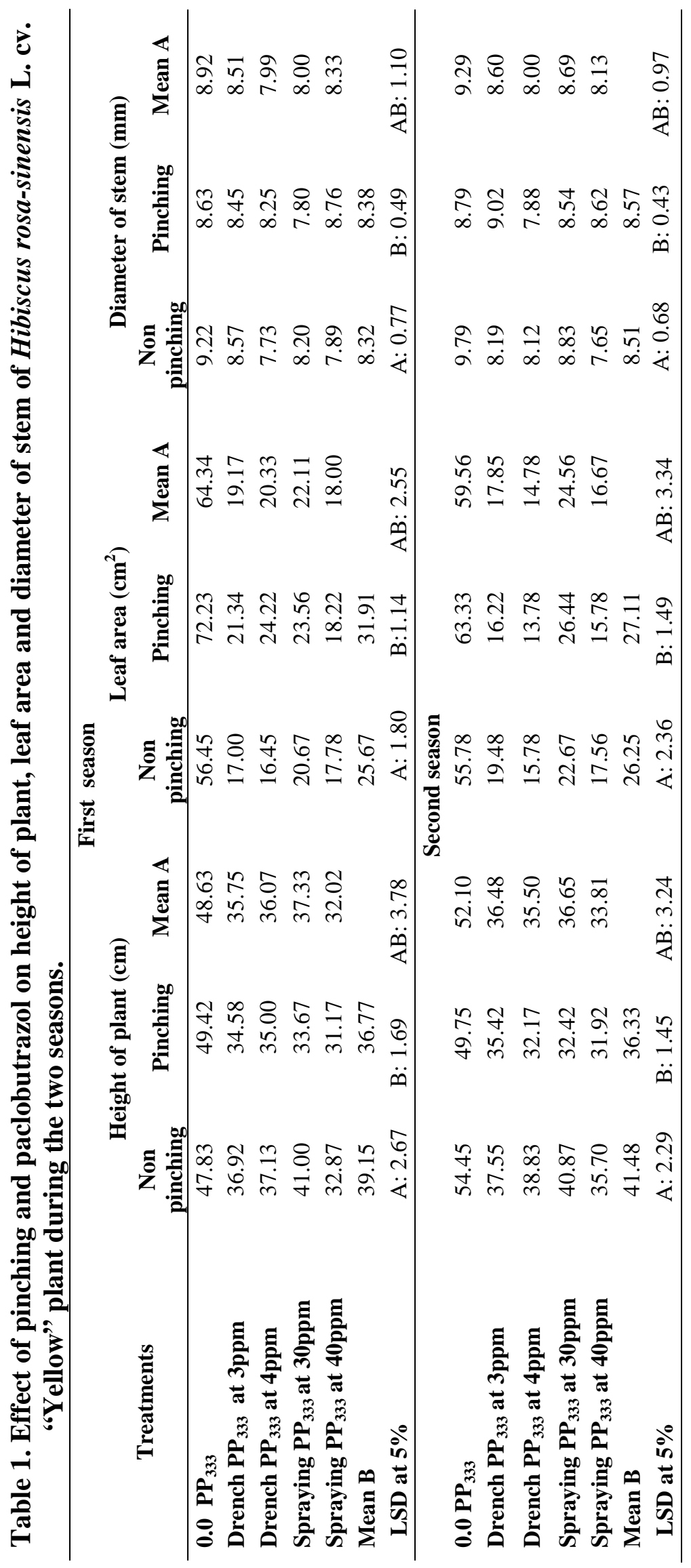




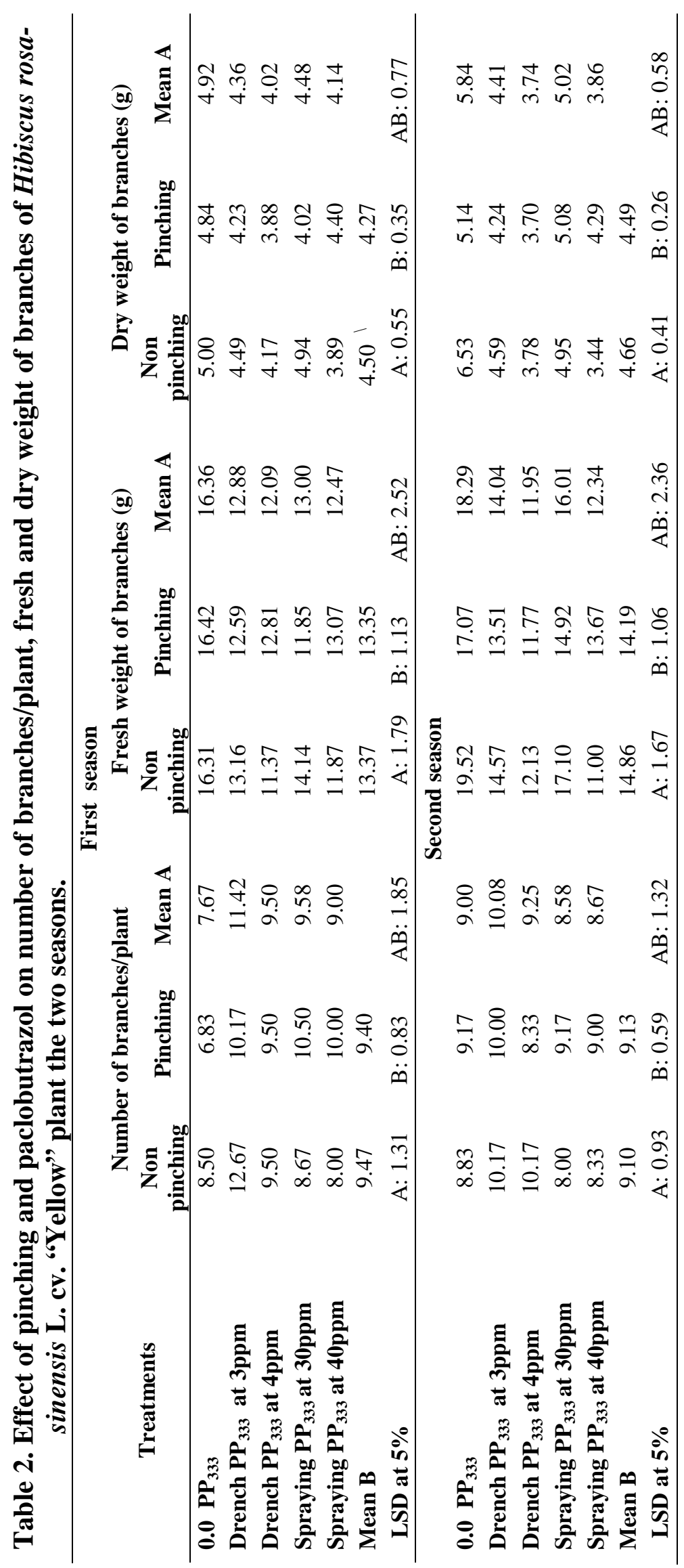




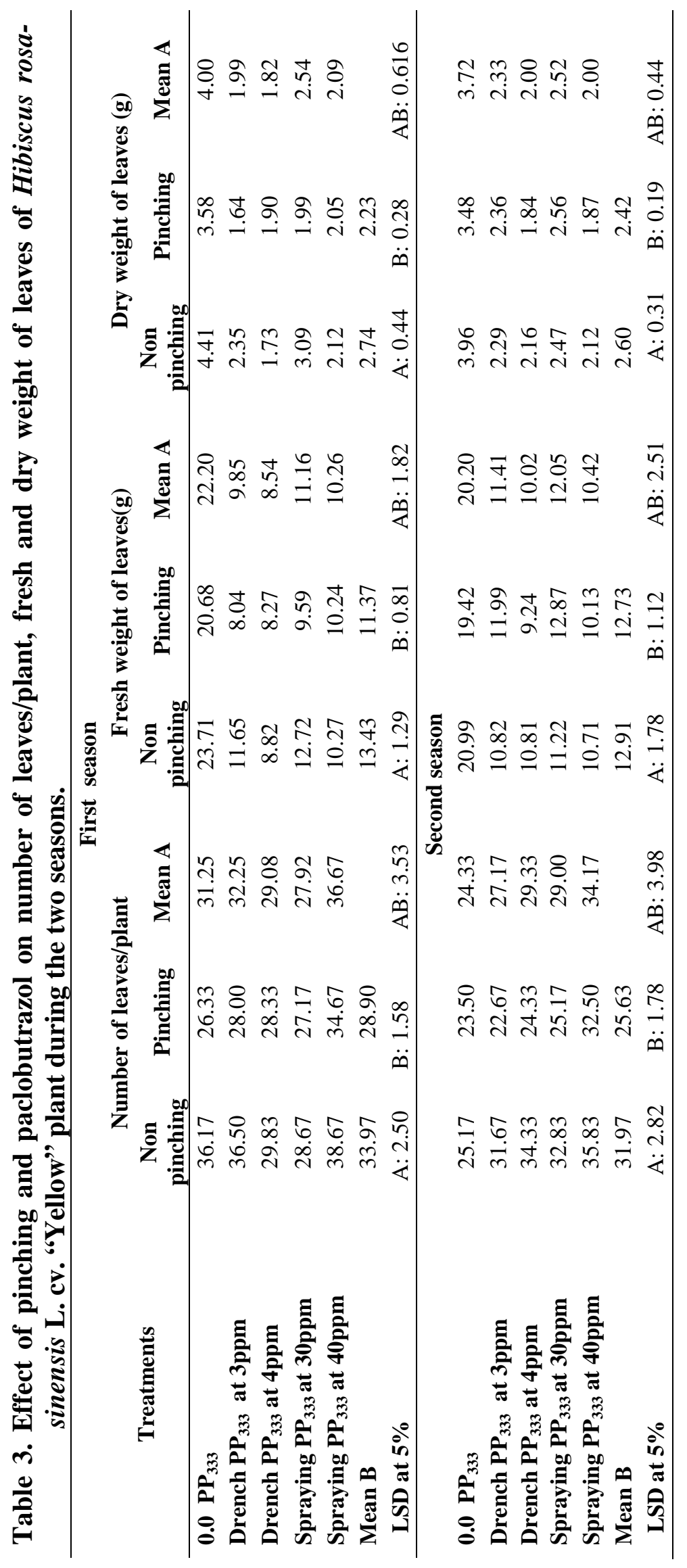




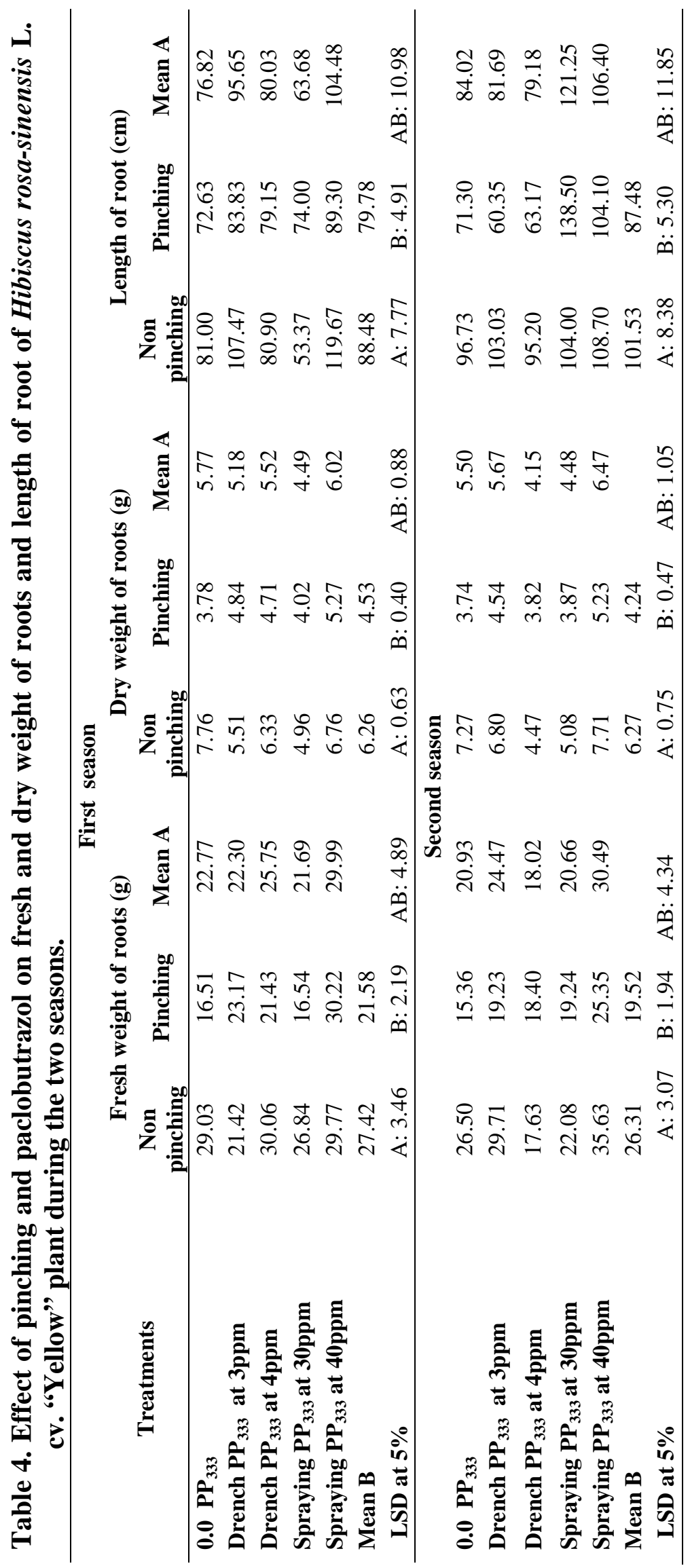


Zeinab H. El-Sadek

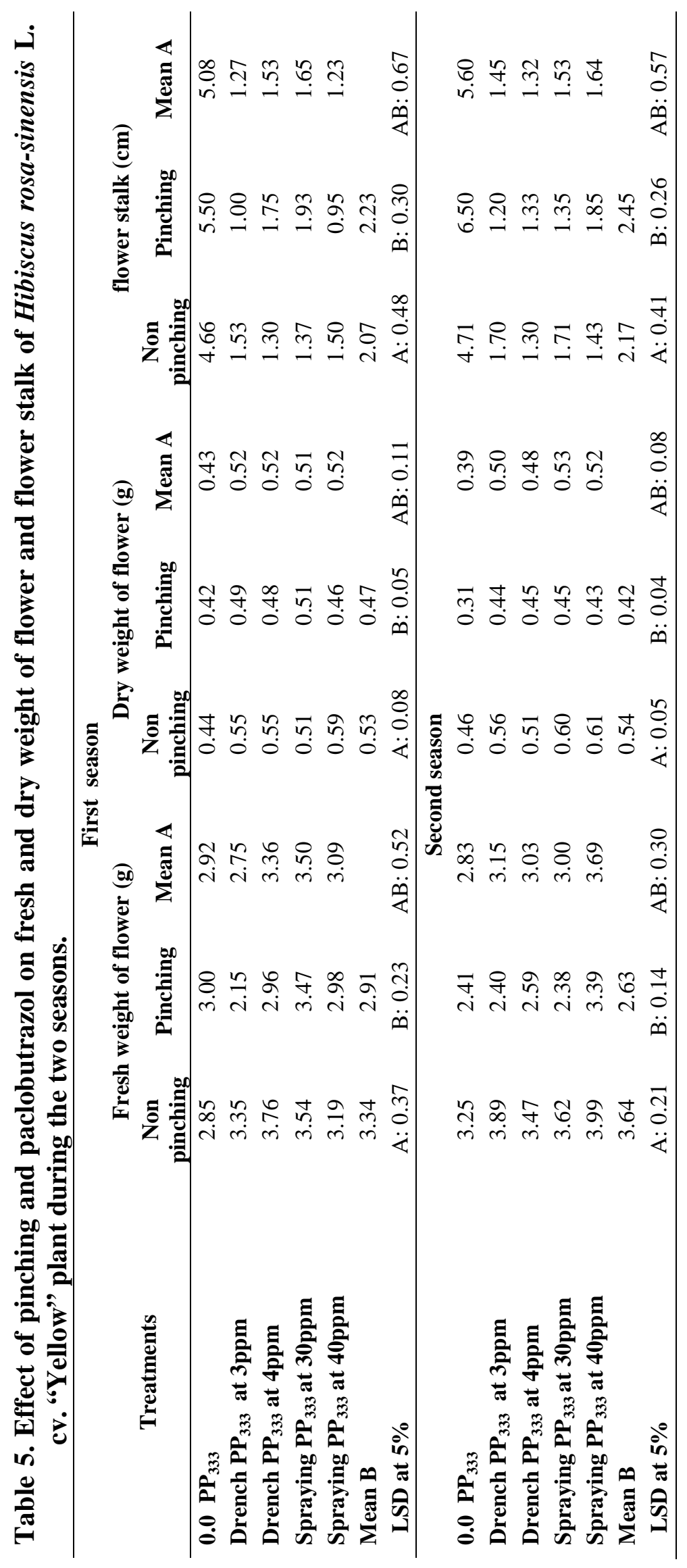


paclobutrazol increased fresh and dry weight of flowers

The interaction between pinching and paclobutrazol showed that spraying plants with paclobutrazol at $40 \mathrm{ppm}$ without pinching increased fresh and dry weight of flowers, also, the untreated pinched plants showed long flower stalks.

\section{Effect of pinching and paclobutrazol on chemical composition:}

Data presented in Tables (6 and 7) show the effect of pinching and paclobutrazol on chemical composition of Hibiscus plants.

Pinching plants increased total carbohydrates, indoles and phenols contents.

Using $\mathrm{PP}_{333}$ increased most of chemical contents in plants compared to untreated plants. These results are in agreement with those by Youssef (2013) on Tabernaemontana coronaria. He found that treating plants with paclobutrazol increased total carbohydrates content of the leaves.

The interaction between pinching and paclobutrazol showed that $\mathrm{PP}_{333}$ at $40 \mathrm{ppm}$ sprayed on pinched plants increased total carbohydrates, indoles and phenols percentages in the leaves.

\section{REFERENCES}

A.O.A.C. (2000). Official Methods of Analysis $16^{\text {th }}$ Ed. A.O.A.C. Benjamin Franklin Station, Washington, D.C., S.A. pp. 490-510.

Carver, S.T.; Arnold, M.A.; Byrne, D.H.; Armitage, A.R.; Lineberger, R.D. and King, A.R. (2014.). Growth and flowering responses of sea marigold to daminozide, paclobutrazol, or uniconazole applied as drenches or sprays. Journal of Plant Growth Regulation, 33(3):626-631.

El-Bably, S.Z. (2008). Growth and flowering of Anisacanthus wrightii plant as affected by cycocel and paclobutrazol application. Alexandria Journal of Agricultural Research, 53(1):73-80.
El-Bably, S.M.Z. and Zaky, A.A. (2009). Efficacy of paclobutrazol on the growth and flowering of Jacobinia carnea (Lindl.) "Nicholson". Bulletin of Faculty of Agriculture, Cairo University, 60(1):86-98.

Fahmy, R. (1970). Quantitative Methods For Organic Compounds Determination In Plant Tissues. Dar-El-Taawen Publ. Cairo.

Herbert, D.; Philips, P.J. and Strange, R.E. (2005). Determination of total carbohydrates. Methods in Microbiology, 58:209:344.

Larsen, P.; Harbo, A.; Klungsoyr, S. and Aasheim, T. (2006). On the biogenesis of some indoles compounds in Acetobacter xylinum. Physiologia plantarum, 15(3): 552-565.

Mead, R.; Curnow, R.N. and Harted, A.M. (1993). Statistical Methods in Agricultural and Experimental Biology. $2^{\text {nd }}$ Ed. Chapman and Hal, London, 1044.

Rezazadeh, A.; Harkess, R.L. and Bi, G.H. (2015). Stimulation of lateral branching of red firespike using dikegulac sodium, benzyladenine, and pinching. Hort. Technology, 25(3):358-362.

Rhonda (2015). Pinching Back Plants. Inter Net Site 1: WWW. naturehils.com/garden-blog/pinchingback-plants.

Songul, S. M. and Ece, A. (2015). Effects of paclobutrazol and pinching on ornamental pepper. Hort. Technology, 25(5): 657-664

Walston, B. (2001). Pruning and Pinching. Inter Net Site 2: WWW. evergreengardenwork.com/pruning, htm

YanHua, H.; Ping, L. and AiLian, S. (2011). Effects of plant growth retardants on Hibiscus rosa-sinensis, L. and Carmona microphylla (Lam.) “G. Don”. Journal of Southern Agriculture; 42(3):284-287. 


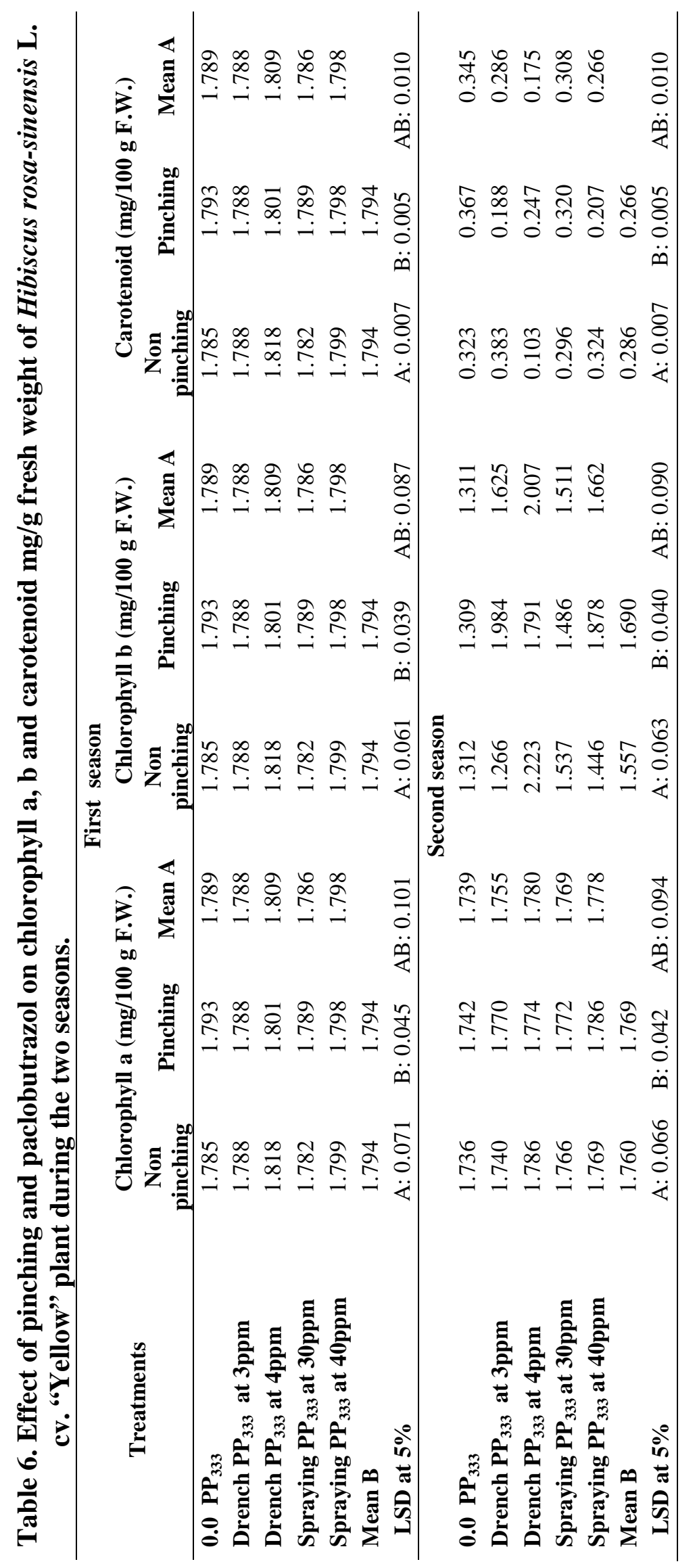




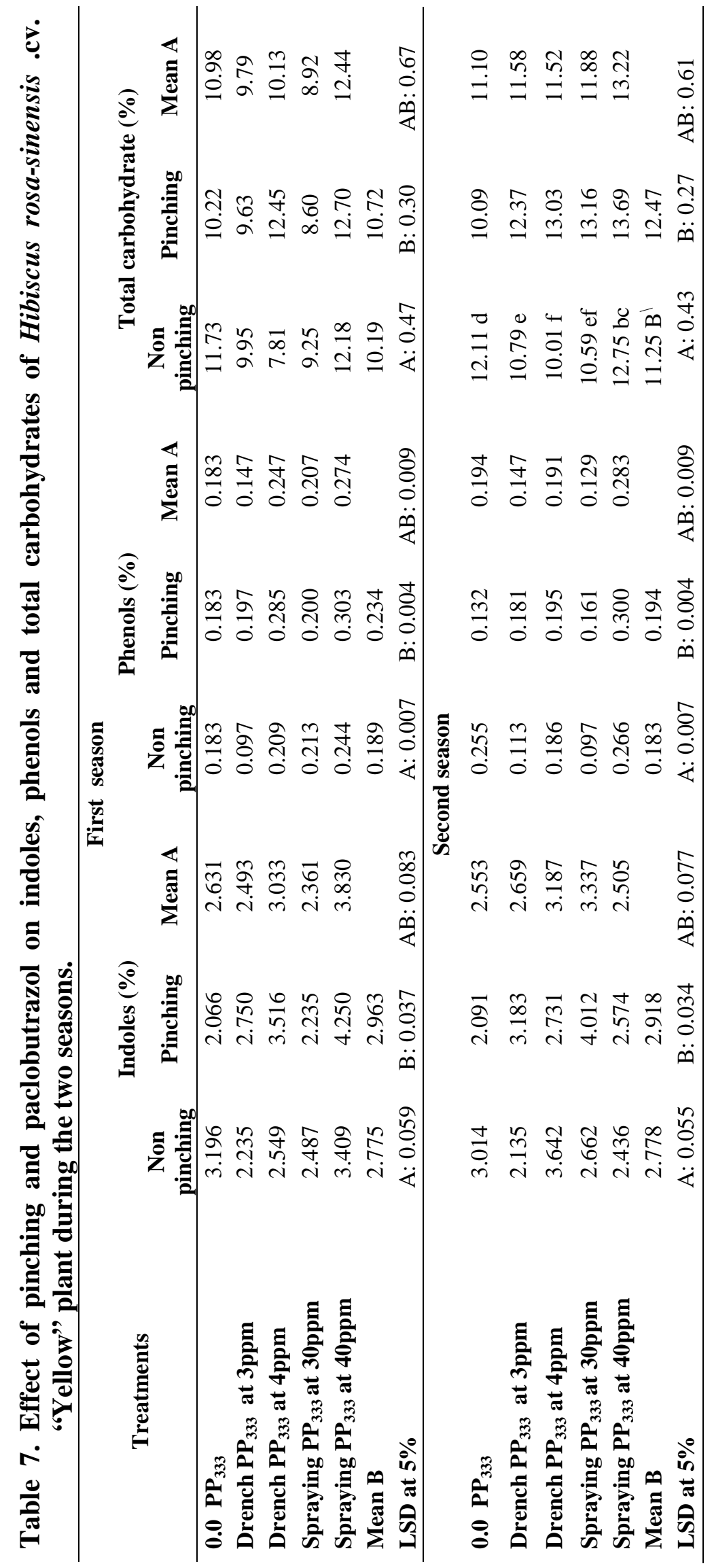




\section{Zeinab H. El-Sadek}

Youssef, A.S.M. and Abd El-Aal M.M.M. (2013). Effect of paclobutrazol and cycocel on growth, flowering, chemical composition and histological features of potted Tabernaemontana coronaria Stapf plant. Journal of Applied Sciences Research, 9(11):5953-5963.

\section{تأثير التطويش والباكلوبترازول على نبات الهبسكس}

$$
\text { زينب حسني الصادق }
$$

قسم بحوث الزينة وتنسيق الحدائق، معهد بحوث البساتين، مركز البحوث الزراعية، الجيزة، مصر.

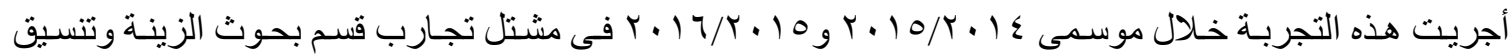

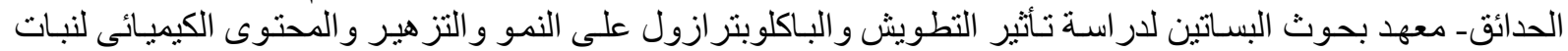

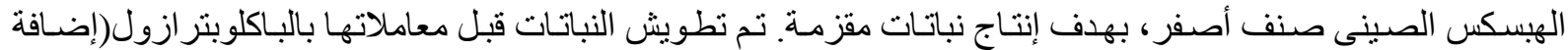

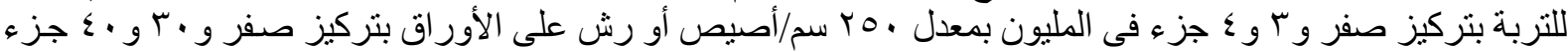

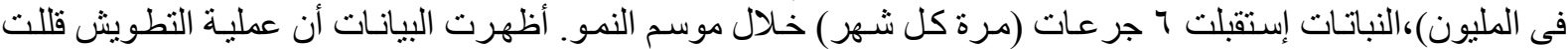

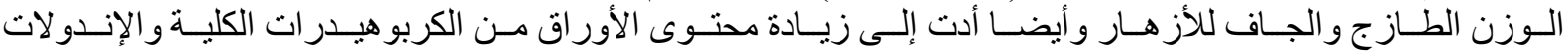

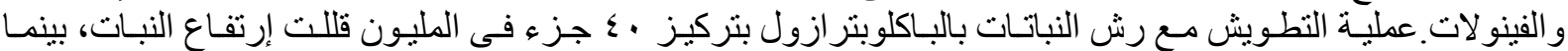

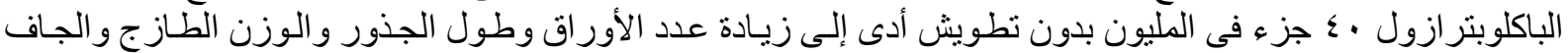

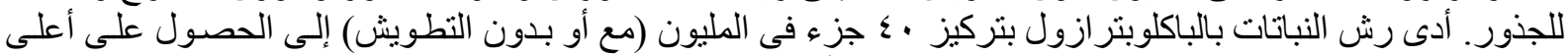

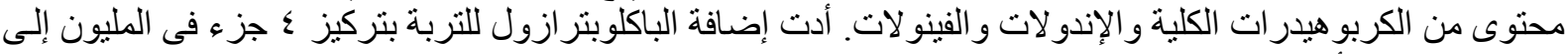

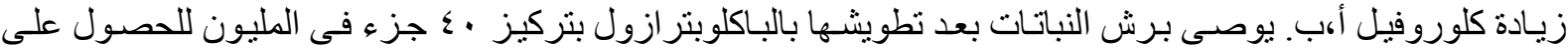

